\title{
The characteristics and changes of psychological immune competence of breast cancer patients receiving hypnosis, music or special attention
}

\author{
ADRIENN, VARGAY ${ }^{1,2 *}$ - EMESE, JÓZSA² - \\ ALEXANDRA, PÁJER² - ÉVA, BÁNYAI² \\ ${ }^{1}$ Doctoral School of Psychology, ELTE Eötvös Loránd University, Budapest, Hungary \\ ${ }^{2}$ Institute of Psychology, ELTE Eötvös Loránd University, Budapest, Hungary
}

(Received: 15 November 2018, accepted: 31 January 2019)

Introduction: Coping mechanism and adaptation skills play an important role in successfully adjusting to breast cancer. The concept of psychological immunity integrates different coping skills that are capacities leading to successful adaptation. Hypnosis as a psychological intervention is effective in increasing coping potentials; nevertheless, there is little empirical evidence on the effectiveness of hypnosis in terms of increasing psychological immunity. Purpose: Our aim was to examine the characteristics and changes of psychological immune competence of breast cancer patients receiving different psychological interventions. Methods: Altogether 61 patients were assigned to receive hypnosis, music, and special attention as adjunctive treatments to standard chemotherapy. Psychological immunity was measured four times with Psychological Immune Competence Inventory (PICI). Results: Differences were detected during treatment on Social Monitoring Capacity $\left(F(2,58)=5.973, p=.006, \omega^{2}=.12\right)$; Problem-Solving Capacity $\left(F(2,58)=4.208, p=.023, \omega^{2}=.10\right)$; Impulse Control $\left(F(2,58)=6.051, p=.005, \omega^{2}=.11\right)$; Emotional Control $\left(F(2,58)=3.612, p=.037, \omega^{2}=.07\right)$ and after the chemotherapy on Sense of Control $\left(F(2,58)=6.548, p=.004, \omega^{2}=.11\right)$; Sense of Coherence $(F(2,58)=4.898, p=.013$; $\left.\omega^{2}=.10\right)$; Problem-Solving Capacity $\left(F(2,58)=3.949, p=.028, \omega^{2}=.08\right)$. Hypnosis-group patients showed higher immune capacity compared to patients in the other two groups. Changes over time were measured and revealed increased psychological immunity based on cumulative PICI $\left(F(3,174)=6.403, p<.001, \eta^{2} p=.10\right)$ and on certain PICI scales in all three groups. Only the scale of Synchronicity showed interactional effects $(F(2,58)=2.508$, $\left.p=.024, \eta^{2} p=.08\right)$. Conclusions: Psychological immune capacity of breast cancer patients seems to increase throughout chemotherapy and follow-up period, independently from the received interventions. Nonetheless hypnosis may have a further facilitating role in the maintenance and development of psychological immunity during cancer treatments.

Keywords: breast cancer, psychological intervention, hypnosis, coping, psychological immune competence

\footnotetext{
* Corresponding author: Adrienn Vargay, Institute of Psychology, Doctoral School of Psychology, ELTE Eötvös Loránd University, H-1064 Budapest, Hungary, Izabella u. 46. E-mail: vargay. adrienn@gmail.com
} 


\section{Introduction}

There is a growing interest in recent psychosocial cancer care towards identifying protective factors that empower individuals to deal with distress, anxiety, and difficulties caused by their diagnoses and treatments. It has been well-established that coping style has a significant and relevant impact on the physical and psychological adjustment to breast cancer (Stanton, Danoff-Burg, \& Cameron, 2000; Shapiro, McCue, Heyman, Dey, \& Haller, 2010; Kvillemo \& Bränström, 2014.). The particular phases and characteristics of breast cancer treatment - such as diagnosis and anticipation, surgery and postoperative treatments with side effects, end of treatment and reintegration - may vary in terms of the type and the degree of the stressors according to which changes may occur in coping response. A person's coping style throughout the course of a chronic disease has individual-specific elements and traits, while the actual coping behaviour is also governed by situational factors (Geyer, Koch-Giesselmann, \& Noeres, 2015; Regier \& Parmelee, 2015; Scheenen, Horn, Koning, Naalt, \& Spikman, 2017). Changes in coping style and effort are, therefore, on the one hand, part of the process of adaptation (Hervatin, Sperlich, Koch-Giesselmann, \& Geyer 2012; Roussi, Krikeli, Hatzidimitriou, \& Koutri, 2007); on the other hand, in line with Lazarus and Folkman's Transactional Model of Stress and Coping (Lazarus \& Folkman, 1984) coping style can be changed by therapy or intervention as adaptive coping techniques are skills that can be modified and acquired. Psychological intervention that incorporates coping skills training seems to provide better adjustment to the disease, reduces symptoms, and increases positive coping (Groarke, Curtis, \& Kerin, 2013; Stagl et al., 2015).

Hypnosis as an intervention - among other benefits - has a long history of increasing better coping and stress reduction (Bargard et al., 2017; Barling \& Raine, 2005; Cardena, Svensson, \& Hejdstrom, 2013; Stanton, 1989). Teaching relaxation techniques has been a part of successful coping skills training for cancer patients (Gudenkauf et al., 2015; Wang et al., 2018). According to Chen, Liu \& Chen's (2017) meta-analysis, hypnosis has been successful in stress management and anxiety-related distress reduction in cancer care. In addition, hypnosis was proven to increase coping skills and resilience (Schoen \& Nowack, 2013).

In order to better understand the interactional nature of successful adaptation, Oláh (2005a) has integrated the different coping skills into the concept of psychological immunity, which is the multidimensional and complex system of personal capacities behind successful adaptation. It grants a certain "immunity" during a stressful or traumatic event. Psychological immune system (PIS) incorporates coping strategies, protective 
personality resources, and dimensions of resilience such as control capacity, learned resourcefulness, constructive thinking, hardiness, dispositional optimism, ego resiliency, and emotional intelligence. Not only does PIS guarantee monitoring, mobilizing, and creating and executing adaptive personal competencies, but it also ensures the functioning of an integrated personality and facilitates self-growth Oláh (2005a).

Psychological immunity has a strong correlation with life-satisfaction and well-being dimensions, such as environmental mastery, purpose in life, personal growth, self-acceptance, positive relations, and autonomy (Oláh, 2009). The protective immune traits of personality, such as Sense of Coherence, Sense of Self-Growth, Synchronicity, Impulse, Emotional Control, and Irritability Control, have a strong correlation with mental and physical health, and almost all scales negatively correlate with burnout (Oláh, 2009). The coping strategies of PIS, such as Positive Thinking, Sense of Control, Sense of Coherence, and Sense of Self-Growth play a mediating role in psychological adjustment and mental health in cases of acute psychopathology (Mirnics et al., 2013). Hungarian oncology patients showed significantly lower results in their psychological components (on 12 out of 16 scales of Psychological Immune Competence Inventory) than the standard, healthy Hungarian population (Oláh, 2005b). Although PIS and its important correlates were measured across different cultures, populations, and life situations (Gupta \& Pandey, 2014; Magyaródi, Nagy, Soltész, Mózes, \& Oláh, 2014; Mirnics et al., 2013; Nagy \& Oláh, 2014; Oláh, Nagy, \& Tóth, 2010; Szicsek, 2004; Voitkane, 2004), we have little information on the psychological immune system of cancer patients, how it behaves along the cancer continuum, and whether it can be modified by psychotherapeutic intervention.

The focus of this paper is to explore the characteristics of the psychological immune competence of breast cancer patients during the chemotherapeutic treatment and the first year after the diagnosis and show how immune competence can be enhanced by psychotherapeutic intervention. Furthermore, our hypothesis was that hypnosis as an adjunctive treatment is more effective than music or special attention treatments.

\section{Methods}

The presented data is part of a prospective, randomized, single-blind, controlled study entitled "PSYHOLOGICAL RESOURCES AND HEALING", which is designed to explore that hypnotherapy administered during chemotherapy has beneficial effects on intermediate and high-risk breast cancer patients in terms of quality of life, psychological immune competence 
as coping resource, and physiological immune activity. The Hungarian Medical Research Council Research Ethics Committee approved this research [15530-0/2010-1018EKU (670/PI/10) and 39447-/2013/EKU (465/2013)]. The effect of hypnotherapy is compared to either that of music as control condition or the data of special attention control groups. Patients received chemotherapy that follows a taxane-antacycline chemotherapy protocol: 4 cycles of Adriamicin and Cyclophosphamide (AC) and 12 cycles of Paclitaxel (PAC) in 24 weeks. While receiving cytostatic infusion or waiting for blood test results, patients listened to either recorded positive suggestions in hypnosis, a music selection with the same dynamism and duration, or received special attention without any further intervention (Bányai, 2013; Bányai et al., 2017).

\subsection{Subjects}

The participants of the study were histologically confirmed, HER2-negative, axillary lymph node-positive or high-risk, lymph node-negative breast cancer patients without distant metastases. All patients receive chemotherapy according to the St. Gallen's Consensus Guideline of 2011 (Goldhirsch et al., 2011) and need to have complete surgical resection. Participants of the hypnosis and music groups were recruited for a study to compare the effectiveness of different interventions and they were randomly assigned to hypnosis or to music as a control group. For ethical considerations, the special attention control group consisted of patients who were recruited to participate in a study that examines the relationship between psychological well-being and biological parameters. The patients were recruited in three distinct oncology centres by their oncologists who described the nature of the study at their first visits. Participation was voluntary with a signed informed consent form. In the present study, psychological immune competence was measured in 61 women aged between $25-72$ years $(\mathrm{M}=56.49$ years, $\mathrm{SD}=11.50$ years $)$. There was no difference in age $(F(2,78)=0.468, p=.630)$, education $\left(\chi^{2}(4)=1.853, p=.763\right)$, and marital status $\left(\chi^{2}(2)=4.682, p=.096\right)$ between the groups. Participants formed 3 groups: Hypnosis $(n=21)$, Music $(n=23)$, and Special Attention $(n=17)$.

\subsection{Measures}

Psychological immune competence was measured by the Psychological Immune Competence Inventory (PICI), a paper-and-pencil instrument of 80 items classified in 16 scales (Oláh, 2005a, b).The 16 scales are: (1) Positive 
Thinking, (2) Sense of Control, (3) Sense of Coherence, (4) Creative SelfConcept, (5) Sense of Self-Growth, (6) Change and Challenge Orientation, (7) Social Monitoring Capacity, (8) Problem-Solving Capacity, (9) SelfEfficacy, (10) Social Mobilizing Capacity, (11) Social Creation Capacity, (12) Synchronicity, (13) Goal Orientation, (14) Impulse Control, (15) Emotional Control, and (16) Irritability Control. These dimensions seem to create an integrated system because, based on research implications, they have the same mode of action and high correlation with PIS (Oláh 2005a; Oláh, 2009). All the 16 scales of PICI contain 5 items that are Likert scales, ranging from 1 to 4 , where 1 means "does not describe me at all," while 4 means "describes me completely."

The psychological immune competence of the patients was measured four times in total: first, before prior to the chemotherapy treatment and psychological intervention; second, 12 weeks after the AC cytostatic protocol; third, at the end of the 12-week PAC treatment; fourth, 1 year after the diagnosis in the follow-up period. The Cronbach's alpha of the PICI scales was between .72 and .89 .

\subsection{Interventions}

Special attention was given to all subjects of the study. Special attention consisted of being accompanied throughout the treatment, being inquired about the physical and emotional well-being of the patients, maintaining a more intensive care for them than for those receiving the regular treatment of the same medical institute. In line with this, 3 types of intervention groups were formed: (1) hypnosis group, receiving special attention and hypnosis, (2) music group, receiving special attention and music, and (3) special attention group, receiving special attention only.

\subsubsection{Hypnosis}

Hypnosis and music were administered 21 times throughout the 24-week AC/PAC cytostatic treatment. Patients listened to pre-recorded hypnosis or music sessions through MP3 players while receiving chemotherapy or waiting for blood test results. A hypnotherapist was present during all sessions. The hypnosis contained relaxation hypnotic induction and suggestions on how to decrease stress-induced anxiety, deal with chemotherapy side-effects (e.g., nausea, hair loss), activate inner healing resources, and facilitate immune functions, as well as metaphors for ego-strengthening and motivation for recovery and finally dehypnosis. This procedure is in 
line with the latest APA definition of hypnosis: "A state of consciousness involving focused attention and reduced peripheral awareness characterized by an enhanced capacity for response to suggestion." (Elkins, Barabasz, Council, \& Spiegel, 2015, p. 6.)

\subsubsection{Music}

Music as a control condition was designed to match the dynamism and the duration of the hypnosis. It was a selection of classical music that intended to follow the different themes of the hypnosis; e.g., stress reduction was matched with soft and calm music, enhancing active coping with the disease was matched with march-like energizing themes, while bodily rebirth via natural symbols was matched with 'program music' implying themes of natural rebirth. The 'message' of the music was voluntarily tested on healthy subjects and cancer patients prior to the study (Bányai \& Vargay, 2013).

\section{Results}

PICI was taken at 4 measuring points. The first one was a baseline measured after the diagnosis and the surgery but before the chemotherapeutic and psychological interventions (T1). The second one was taken after 12 weeks of the treatment (T2); the third one at the end of the chemotherapeutic treatment, 24 weeks after the diagnosis and the surgery (T3); and the fourth 1 year after the diagnosis (T4).

In the first analysis, the three groups (hypnosis, music, special attention) were compared by a between-subject method to evaluate differences in PICI. Subsequently, the effect of time was examined by a within-subject method to detect the changes in time according to groups.

\subsection{Comparison of cumulative PICI and PICI scales between groups}

The differences between the three intervention groups were compared at each measuring point by using one-way ANOVA with robust F and GamesHowell post-hoc test. 


\subsubsection{Comparison of cumulative PICI}

General immune competence can be described by the cumulative PICI score (i.e., by adding up the scores of all the scales). When the cumulative scores were compared between the three groups at the four measuring points, PICI showed significant differences between the groups $(F(2,58)=4.054$, $p=.026, \omega^{2}=.07$ ) at the end of the chemotherapy (T3): hypnosis scored higher than music or special attention. There was no statistical difference at the other measuring points; based on the average value, hypnosis showed slightly higher scoring compared to music or special attention; however, the $\omega^{2}$ indicated medium effect at T2 (Table 1).

Table 1. Descriptive statistics of cumulative PICI results between the three groups at the four measuring points

\begin{tabular}{|l|c|c|c|c|c|c|c|c|c|}
\hline & \multicolumn{2}{|c|}{$\begin{array}{c}\text { Hypnosis } \\
(n=21)\end{array}$} & \multicolumn{2}{c|}{$\begin{array}{c}\text { Music } \\
(n=23)\end{array}$} & \multicolumn{2}{c|}{$\begin{array}{c}\text { Special } \\
\text { Attention }(n=17)\end{array}$} & F & p & $\omega^{2}$ \\
\cline { 2 - 10 } & M & SD & M & SD & M & SD & & & \\
\hline PICI_T_1 & 236.81 & 28.44 & 224.39 & 38.86 & 221.71 & 34.14 & 1.312 & .282 & .00 \\
\hline PICI_T_2 & 243.81 & 28.86 & 222.09 & 31.91 & 224.59 & 37.93 & 3.133 & .056 & .05 \\
\hline PICI_T_3 & 249.38 & 24.36 & 226.65 & 36.71 & 225.88 & 39.75 & 4.054 & $.026^{*}$ & .07 \\
\hline PICI_T_4 & 246.33 & 30.89 & 233.65 & 30.91 & 233.94 & 42.93 & 1.033 & .367 & .00 \\
\hline
\end{tabular}

\subsubsection{Comparison of PICI scales}

Out of the 16 scales, only Problem-Solving Capacity showed a difference at $\mathrm{T} 1$ (baseline) $\left(F(2,58)=4.197, p=.023, \omega^{2}=.09\right)$. Hypnosis scored higher than music or special attention.

There were significant differences between the groups on 4 PICI scales at the T2 measuring point (after 12 weeks of treatment): Social Monitoring Capacity $\left(F(2,58)=5.973, p=.006, \omega^{2}=.12\right)$; Problem-Solving Capacity $\left(F(2,58)=4.208, p=.023, \omega^{2}=.10\right)$; Impulse Control $(F(2,58)=6.051, p=.005$, $\left.\omega^{2}=.11\right)$;Emotional Control $\left(F(2,58)=3.612, p=.037, \omega^{2}=.07\right)$.

There were significant differences between the groups on 3 PICI scales at the T3 measuring point (at the end of the chemotherapeutic treatment): Sense of Control $\left(F(2,58)=6.548, p=.004, \omega^{2}=.11\right)$; Sense of Coherence $\left(F(2,58)=4.898, p=.013 ; \omega^{2}=.10\right)$; Problem-Solving Capacity $(F(2,58)=$ $\left.3.949, p=.028, \omega^{2}=.08\right)$ (Table 2). 
There were no significant differences between the three groups at T4 (one year after the diagnosis).

On all the significant scales, based on the Games-Howell post-hoc test, the hypnosis group showed significantly higher score than the music or special attention groups.

Table 2. Significant differences between the three groups at T1, T2, and T3.

\begin{tabular}{|c|c|c|c|c|c|c|c|c|c|}
\hline \multirow[t]{3}{*}{ T1 } & \multicolumn{2}{|c|}{$\begin{array}{l}\text { Hypnosis } \\
\text { (H) }\end{array}$} & \multicolumn{2}{|c|}{ Music (M) } & \multicolumn{2}{|c|}{$\begin{array}{c}\text { Special } \\
\text { Attention } \\
\text { (SA) }\end{array}$} & $F$ & \multirow[t]{3}{*}{$p$} & Post-Hoc \\
\hline & \multicolumn{2}{|c|}{$(n=21)$} & \multicolumn{2}{|c|}{$(n=23)$} & \multicolumn{2}{|c|}{$(n=17)$} & & & \multirow{2}{*}{$\begin{array}{l}\text { Games- } \\
\text { Howell }\end{array}$} \\
\hline & M & SD & $\mathbf{M}$ & SD & $\mathbf{M}$ & SD & & & \\
\hline $\begin{array}{l}\text { Problem-Solving } \\
\text { Capacity }\end{array}$ & 15.67 & 3.32 & 12.74 & 3.40 & 13.71 & 3.62 & 4.197 & .023 & $\mathrm{H}>\mathrm{M}=\mathrm{SA}$ \\
\hline \multirow[t]{3}{*}{ T2 } & \multicolumn{2}{|c|}{$\begin{array}{l}\text { Hypnosis } \\
\text { (H) }\end{array}$} & \multicolumn{2}{|c|}{ Music (M) } & \multicolumn{2}{|c|}{$\begin{array}{l}\text { Special } \\
\text { Attention } \\
\text { (SA) }\end{array}$} & $F$ & \multirow[t]{3}{*}{$p$} & Post-Hoc \\
\hline & \multicolumn{2}{|c|}{$(n=21)$} & \multicolumn{2}{|c|}{$(n=23)$} & \multicolumn{2}{|c|}{$(n=17)$} & & & \multirow{2}{*}{$\begin{array}{l}\text { Games- } \\
\text { Howell }\end{array}$} \\
\hline & $\mathbf{M}$ & SD & $\mathbf{M}$ & SD & M & SD & & & \\
\hline $\begin{array}{l}\text { Social Monitoring } \\
\text { Capacity }\end{array}$ & 15.24 & 2.55 & 12.39 & 3.07 & 13.12 & 3.50 & 5.973 & .006 & $\mathrm{H}>\mathrm{M}=\mathrm{SA}$ \\
\hline $\begin{array}{l}\text { Problem-Solving } \\
\text { Capacity }\end{array}$ & 15.91 & 2.95 & 13.70 & 2.85 & 13.35 & 3.32 & 4.208 & .023 & $\mathrm{H}>\mathrm{M}=\mathrm{SA}$ \\
\hline Impulse Control & 15.95 & 2.01 & 13.65 & 3.23 & 13.94 & 2.22 & 6.051 & .005 & $\mathrm{H}>\mathrm{M}=\mathrm{SA}$ \\
\hline Emotional Control & 13.24 & 3.02 & 10.74 & 3.09 & 12.00 & 3.74 & 3.612 & 0.037 & $\mathrm{H}>\mathrm{M}=\mathrm{SA}$ \\
\hline \multirow[t]{3}{*}{ T3 } & \multicolumn{2}{|c|}{$\begin{array}{l}\text { Hypnosis } \\
\text { (H) }\end{array}$} & \multicolumn{2}{|c|}{ Music (M) } & \multicolumn{2}{|c|}{$\begin{array}{l}\text { Special } \\
\text { Attention } \\
\text { (SA) }\end{array}$} & $F$ & \multirow[t]{3}{*}{$p$} & Post-Hoc \\
\hline & \multicolumn{2}{|c|}{$(n=21)$} & \multicolumn{2}{|c|}{$(n=23)$} & \multicolumn{2}{|c|}{$(n=17)$} & & & \multirow{2}{*}{$\begin{array}{l}\text { Games- } \\
\text { Howell }\end{array}$} \\
\hline & $\mathbf{M}$ & SD & $\mathbf{M}$ & SD & $\mathbf{M}$ & SD & & & \\
\hline Sense of Control & 16.29 & 1.85 & 14.22 & 2.15 & 14.29 & 3.26 & 6.548 & .004 & $\mathrm{H}>\mathrm{M}=\mathrm{SA}$ \\
\hline $\begin{array}{l}\text { Sense of } \\
\text { Coherence }\end{array}$ & 17.38 & 2.82 & 14.91 & 3.48 & 14.77 & 3.07 & 4.898 & .013 & $\mathrm{H}>\mathrm{M}=\mathrm{SA}$ \\
\hline $\begin{array}{l}\text { Problem-Solving } \\
\text { Capacity }\end{array}$ & 15.95 & 2.92 & 13.52 & 2.89 & 14.06 & 3.68 & 3.949 & .028 & $\mathrm{H}>\mathrm{M}=\mathrm{SA}$ \\
\hline
\end{tabular}

The cumulative PICI and PICI scale scores were compared between T1, $\mathrm{T} 2, \mathrm{~T} 3$, and T4 to measure the changes in Time considering Groups (4x3 repeated measures factorial ANOVA). 


\subsection{Effect of time on cumulative PICI and PICI scales depending on groups}

\subsubsection{Effect of time on cumulative PICI}

In this repeated measures model, Time had a significant main effect $\left(F(3,174)=6.403, p<.001 ;\right.$ partial $\eta^{2}=.10$. Cumulative PICI score at $\mathrm{T} 4(M=$ $238.10 ; S D=34.58)$ was significantly higher than at $\mathrm{T} 1(M=227.92 ; S D=$ $34.31)$ and $\mathrm{T} 2(M=230.26 ; S D=33.67)$. T3 showed an intermediate value ( $M$ $=234.26 ; S D=35.15)$. Time $\times$ Groups interaction was non-significant $\left(F(6,174)=1.088 ; p=.371 ;\right.$ partial $\left.\eta^{2}=.04\right)$.

\subsubsection{Effect of time on PICI scales}

No statistically significant main effects and interactions were detected on 9 scales out of 16 . There were significant changes in time in the case of 5 scales on which the Time main effect was significant and Time $x$ Group was non-significant. Descriptive statistics of scales on which the Time main effect was significant is presented in Table 3.

Table 3. Descriptive statistics on PICI scales with significant Time main effect.

\begin{tabular}{|c|c|c|c|c|c|c|c|c|c|c|c|c|c|}
\hline & \multicolumn{6}{|c|}{ Positive thinking } & & \multicolumn{6}{|c|}{ Sense of Coherence } \\
\hline & \multirow{2}{*}{\multicolumn{2}{|c|}{$\begin{array}{l}\text { Hypnosis } \\
(n=21)\end{array}$}} & \multirow{2}{*}{\multicolumn{2}{|c|}{$\begin{array}{l}\text { Music } \\
(n=23)\end{array}$}} & \multirow{2}{*}{\multicolumn{2}{|c|}{$\begin{array}{c}\begin{array}{c}\text { Special } \\
\text { Attention }\end{array} \\
(n=17)\end{array}$}} & & \multirow{2}{*}{\multicolumn{2}{|c|}{$\begin{array}{l}\text { Hypnosis } \\
(n=21)\end{array}$}} & \multirow{2}{*}{\multicolumn{2}{|c|}{$\begin{array}{l}\text { Music } \\
(n=23)\end{array}$}} & \multirow{2}{*}{\multicolumn{2}{|c|}{$\begin{array}{c}\begin{array}{c}\text { Special } \\
\text { Attention }\end{array} \\
(n=17)\end{array}$}} \\
\hline & & & & & & & & & & & & & \\
\hline & $\mathbf{M}$ & SD & $\mathbf{M}$ & SD & $\mathbf{M}$ & SD & & $\mathbf{M}$ & SD & $\mathbf{M}$ & SD & $\mathbf{M}$ & SD \\
\hline $\mathrm{T} 1$ & 16.33 & 3.86 & 15.35 & 3.74 & 14.77 & 3.19 & $\mathrm{~T} 1$ & 15.10 & 3.02 & 14.70 & 3.83 & 14.94 & 2.95 \\
\hline $\mathrm{T} 2$ & 15.81 & 3.44 & 5.83 & 3.59 & 14.59 & 3.26 & $\mathrm{~T} 2$ & 16.00 & 2.63 & 14.74 & 3.05 & 14.47 & 3.24 \\
\hline T3 & 17.24 & 2.64 & 16.17 & 3.59 & 15.24 & 3.17 & T3 & 17.38 & 2.82 & 14.91 & 3.48 & 14.77 & 3.07 \\
\hline \multirow[t]{5}{*}{$\mathrm{T} 4$} & 16.95 & 3.38 & 16.17 & 3.10 & 15.94 & 4.34 & $\mathrm{~T} 4$ & 16.05 & 2.92 & 15.78 & 2.58 & 15.29 & 4.04 \\
\hline & \multicolumn{6}{|c|}{ Sense of Control } & & \multicolumn{6}{|c|}{ Impulse Control } \\
\hline & \multicolumn{2}{|c|}{ Hypnosis } & \multicolumn{2}{|c|}{ Music } & \multicolumn{2}{|c|}{$\begin{array}{c}\text { Special } \\
\text { Attention }\end{array}$} & & \multicolumn{2}{|c|}{ Hypnosis } & \multicolumn{2}{|c|}{ Music } & \multicolumn{2}{|c|}{$\begin{array}{c}\text { Special } \\
\text { Attention }\end{array}$} \\
\hline & \multicolumn{2}{|c|}{$(n=21)$} & \multicolumn{2}{|c|}{$(n=23)$} & \multicolumn{2}{|c|}{$(n=17)$} & & \multicolumn{2}{|c|}{$(n=21)$} & \multicolumn{2}{|c|}{$(n=23)$} & \multicolumn{2}{|c|}{$(n=17)$} \\
\hline & $\mathbf{M}$ & SD & $\mathbf{M}$ & SD & $\mathbf{M}$ & SD & & $\mathbf{M}$ & SD & $\mathbf{M}$ & SD & $\mathbf{M}$ & SD \\
\hline $\mathrm{T} 1$ & 14.86 & 1.96 & 15.00 & 2.26 & 14.12 & 2.67 & $\mathrm{~T} 1$ & 13.95 & 1.66 & 13.52 & 3.62 & 12.94 & 3.07 \\
\hline $\mathrm{T} 2$ & 14.95 & 2.82 & 14.57 & 2.66 & 14.00 & 2.94 & $\mathrm{~T} 2$ & 15.95 & 2.01 & 13.65 & 3.23 & 13.94 & 2.22 \\
\hline T3 & 16.29 & 1.85 & 14.22 & 2.15 & 14.29 & 3.26 & T3 & 15.10 & 1.87 & 13.87 & 3.40 & 13.24 & 3.09 \\
\hline $\mathrm{T} 4$ & 16.05 & 2.33 & 15.17 & 2.12 & 15.24 & 2.75 & $\mathrm{~T} 4$ & 15.00 & 1.58 & 13.96 & 2.50 & 13.53 & 2.48 \\
\hline
\end{tabular}




\begin{tabular}{|c|c|c|c|c|c|c|}
\hline \multirow{4}{*}{} & \multicolumn{5}{|c|}{ Emotional Control } \\
\cline { 2 - 7 } & \multicolumn{2}{|c|}{ Hypnosis } & \multicolumn{2}{|c|}{ Music } & \multicolumn{2}{c|}{$\begin{array}{c}\text { Special } \\
\text { Attention }\end{array}$} \\
\cline { 2 - 7 } & \multicolumn{2}{|c|}{$(n=\mathbf{2 1 )}$} & \multicolumn{2}{c|}{$(n=\mathbf{2 3})$} & \multicolumn{2}{c|}{$(n=\mathbf{1 7})$} \\
\cline { 2 - 7 } & $\mathbf{M}$ & SD & $\mathbf{M}$ & SD & M & SD \\
\hline T1 & 10.95 & 2.04 & 10.96 & 4.20 & 11.06 & 2.41 \\
\hline T2 & 13.24 & 3.02 & 10.74 & 3.09 & 12.00 & 3.74 \\
\hline T3 & 13.05 & 2.89 & 11.35 & 3.34 & 12.24 & 3.96 \\
\hline T4 & 13.43 & 2.64 & 11.61 & 3.03 & 11.94 & 3.45 \\
\hline
\end{tabular}

Solely Group main effect was significant on the Problem-Solving Capacity scale. The hypnosis group scored significantly higher than the special attention and the music groups, independently of Time (Table 4). Based on the comparison of the PICI scales between the three groups - see the previous results - this Group main effect was expected.

Table 4. Descriptive statistics of PICI scale with significant Group main effect

\begin{tabular}{|l|c|c|c|c|c|c|}
\hline \multirow{2}{*}{} & \multicolumn{6}{|c|}{ Problem Solving Capacity } \\
\cline { 2 - 7 } & \multicolumn{2}{|c|}{$\begin{array}{c}\text { Hypnosis } \\
(n=21)\end{array}$} & \multicolumn{2}{c|}{$\begin{array}{c}\text { Music } \\
(n=23)\end{array}$} & \multicolumn{2}{c|}{$\begin{array}{c}\text { Special Attention } \\
(n=17)\end{array}$} \\
\cline { 2 - 7 } & $\mathbf{M}$ & SD & M & SD & M & SD \\
\hline T1 & 15.67 & 3.32 & 12.74 & 3.40 & 13.71 & 3.62 \\
\hline T2 & 15.91 & 2.95 & 13.70 & 2.85 & 13.35 & 3.32 \\
\hline T3 & 15.95 & 2.92 & 13.52 & 2.89 & 14.06 & 3.68 \\
\hline T4 & 15.48 & 2.62 & 14.13 & 2.24 & 14.41 & 3.94 \\
\hline
\end{tabular}

Solely Time $\times$ Group interaction revealed significant results in Synchronicity. In the music and the special attention groups, the value of this scale continuously increased throughout T1-T4, while the hypnosis group showed increasing values throughout T1-T3. However, at T4, it decreased compared to T3; at the same time, the value of T4 was higher than at T1, T2 (Figure 1). 


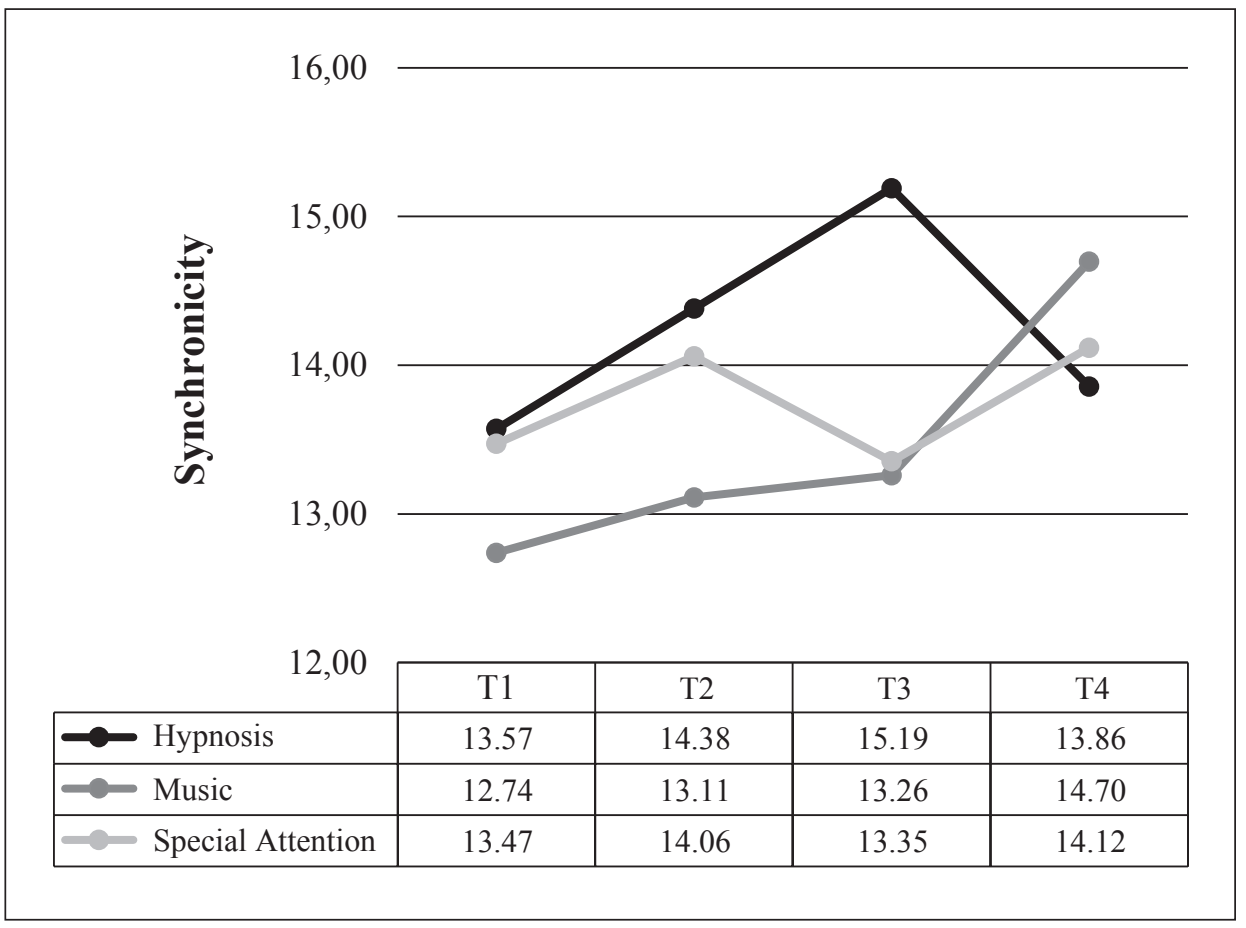

Figure 1. Time $\times$ Group interaction on the scale of Synchronicity

Further 9 scales out of 16 PICI scales showed non-significant main effects and interactions (Table 5).

Table 5. The effect of Time and Group on the 16 scales of PICI.

\begin{tabular}{|l|c|c|c|c|c|c|c|c|c|}
\hline & \multicolumn{3}{|c|}{ Time } & \multicolumn{3}{c|}{ Group } & \multicolumn{3}{c|}{ Time $\times$ Group } \\
\cline { 2 - 11 } & $F$ & $p$ & $\eta_{p}^{2}$ & $F$ & $p$ & $\eta_{p}^{2}$ & $F$ & $p$ & $\eta_{p}^{2}$ \\
\hline Positive Thinking & 4.590 & .004 & .07 & 1.027 & .365 & .03 & .678 & .668 & .02 \\
\hline Sense of Control & 3.687 & .013 & .06 & 1.694 & .193 & .05 & 1.736 & .115 & .06 \\
\hline Sense of Coherence & 2.806 & .041 & .05 & 1.322 & .274 & .04 & 2.102 & .055 & .07 \\
\hline Creative Self Concept & 1.918 & .128 & .03 & 0.883 & .419 & .03 & .532 & .784 & .02 \\
\hline Sense of Self Growth & 0.994 & .397 & .02 & 0.619 & .542 & .02 & 1.548 & .165 & .05 \\
\hline
\end{tabular}




\begin{tabular}{|c|c|c|c|c|c|c|c|c|c|}
\hline & & Time & & & roup & & Tim & $\times \mathrm{Gr}$ & \\
\hline & $F$ & $p$ & $\eta_{p}^{2}$ & $F$ & $p$ & $\eta_{p}^{2}$ & $F$ & $p$ & $\eta_{p}^{2}$ \\
\hline $\begin{array}{l}\text { Change and Challenge } \\
\text { Orientation }\end{array}$ & 1.086 & .375 & .02 & 2.411 & .099 & .08 & 1.251 & .283 & .04 \\
\hline $\begin{array}{l}\text { Social Monitoring } \\
\text { Capacity }\end{array}$ & 0.948 & .419 & .02 & 1.980 & .147 & .06 & 2.093 & .056 & .07 \\
\hline $\begin{array}{l}\text { Problem-Solving } \\
\text { Capacity }\end{array}$ & 1.696 & .170 & .03 & 3.859 & .027 & .12 & 1.430 & .205 & .05 \\
\hline Self-Efficacy & 2.160 & .094 & .04 & 1.270 & .288 & .04 & .102 & .996 & .00 \\
\hline $\begin{array}{l}\text { Social Mobilizing } \\
\text { Capacity }\end{array}$ & 1.518 & .212 & .03 & .105 & .901 & .00 & .200 & .976 & .01 \\
\hline $\begin{array}{l}\text { Social Creating } \\
\text { Capacity }\end{array}$ & 1.563 & .200 & .03 & 2.362 & .103 & .08 & .125 & .993 & .00 \\
\hline Synchronicity & 2.490 & .062 & .04 & .342 & .712 & .01 & 2.508 & .024 & .08 \\
\hline Goal-Orientation & 1.374 & .252 & .02 & 1.739 & .185 & .06 & .860 & .525 & .03 \\
\hline Impulse Control & 3.818 & .011 & .06 & 2.857 & .066 & .09 & 1.208 & .304 & .04 \\
\hline Emotional Control & 6.027 & .001 & .09 & 1.666 & .198 & .05 & 1.842 & .094 & .06 \\
\hline Irritability Control & .306 & .821 & .01 & .260 & .772 & .01 & .494 & .812 & .02 \\
\hline
\end{tabular}

\section{Discussion}

This study aimed to reveal the changes in the integrated cognitive, motivational, and behavioural personality dimensions of psychological immune competence throughout the treatment of breast cancer patients who received psychological intervention. The effects of both therapeutic intervention (hypnosis, music, or special attention) and time were followed. In our understanding, this was the first study investigating psychological immune competence - an integrated personality resource behind the capacity of successful coping, adaptation, and growth - in the case of a homogeneous group of breast cancer patients who received standardized chemotherapeutic treatment and psychological intervention in a longitudinal design.

The level of psychological immunity was increasing, independently from interventions, as the cancer treatment proceeded. This may reflect that successful coping with the disease itself results in the patient's perception of 
an increased psychological immune competence. Comparing the three groups, hypnosis seemed to facilitate the increase during the chemotherapeutic treatment and showed higher means with small-medium effect.

Comparing PICI scales at each measuring point, at T2 (after 12 weeks of AC treatment) and T3 (at the end of the 24-week chemotherapy treatment), the scales measuring psychological immune competence reflected differences between the intervention groups. These differences revealed that patients in the hypnosis group showed higher immune competence than those in the music or the special attention groups. At T4, one year after the diagnosis in the follow-up period, when patients received no chemotherapy or psychological intervention, there was no significant difference between the three groups. This result may highlight that when PI is activated in an acute crisis, psychological interventions support its functioning in different ways and to different extent. Therefore, it may be possible that during this active period hypnosis as an intervention has a greater effect on the functioning of PI. The direct suggestions of hypnosis offer clear, ready-to-use coping strategies, while in the case of music and special attention, patients learn to develop their own strategies. At T4, this acute crisis that activates the psychological immune capacity is no longer there, but the posttraumatic growth may already have begun. This could explain the differences between groups at T2, T3, and the disappearance of this difference at $\mathrm{T} 4$.

The facilitating role of hypnosis is the most dominant during the chemotherapeutic treatment at T2: the hypnosis group scored higher in Social Monitoring Capacity, Emotional and Impulse Controls, and ProblemSolving Capacity. Social Monitoring Capacity helps in building a social network by enabling one to better decode meta-communicative messages, to better understand covert relations between people, and by motivating an individual to explore social behaviour and to use these skills to reach longterm goals. The interpersonal and relational nature of hypnosis (Shor, 1962) may explain the improvement of Social Monitoring Capacity. It may promote those coping potentials that help in both building and maintaining the social support and network, which were proven to be very important for cancer patients (Schroevers, Helgeson, Sanderman \& Ranchor, 2009; Usta, 2012). Furthermore, it may facilitate the communication and interaction with healthcare professionals and the orientation in health services (Cegala, 2003; D'Agostino et al., 2017). Hypnosis also facilitates Emotional and Impulse Controls. In psychological immunity, both control functions help in regulating emotions that overwhelm a momentary state and, as a result, re-orient the person towards realistic and logical actions. Both have a stabilizing role in personality functioning during the process of coping. 
Those who have high Impulse Control make decisions in an exceedingly thoughtful manner. Decision-making on the cancer continuum has a high impact on the physical and mental well-being of the patients, to which emotional factors contribute a great deal (Reyna, Nelson, Han, \& Pignone, 2015). Emotional control helps in regulating especially negative feelings, it facilitates the person to distance themselves from unaffirmative emotions and achieve their goals. Emotional Control, in this sense, is similar to engagement emotional regulation strategies which, in the case of cancer patients, was connected to well-being, positive emotions, especially for patients with low hopes, and post-traumatic growth (Conley, Bishop, \& Andersen, 2016). Problem-Solving Capacity was significantly higher in the hypnosis group at the beginning of the chemotherapy at T1, which remained constant/the same throughout the course of the treatment (T2, T3). Problem-Solving Capacity on the PIS is linked to creative new ideas, alternative solutions and the belief that the person is capable of finding new possibilities in a difficult life situation. Effective problem-solving capacity in the case of cancer patients may be an important moderator in experiencing decreased distress and depression that are generally connected to the disease (Carvalho \& Hopko, 2009; Hopko et al., 2011; Nezu, Nezu, Felgoise, McClure, \& Houts, 2003).

At the end of the chemotherapy (T3), there were also detectable differences between the three intervention groups on three PICI scales: Sense of Coherence, Sense of Control, and Problem-Solving Capacity. In all three cases, scores were higher in the hypnosis group than in the music or the special attention groups. Sense of Control in the Psychological Immune System is accompanied with the belief in personal influence over life events. It is associated with decreased distress in the case of breast cancer patients (Henselmans et al., 2010) because it helps them in building on active coping strategies (e.g., positive reframing; Kim, Han, Shaw, McTavish \& Gustafson, 2010), which is why it was a notable result of the study at hand that hypnosis proved to be the most effective intervention to mobilise these capacities. Sense of Coherence in psychological immunity helps the person in believing that life is comprehensible and governable. It helps in predicting a positive outcome as a result of coherent events. High Sense of Coherence also has its significance on the cancer continuum: haematological cancer survivors with high level of coherence were less concerned with relapse and showed lower levels of PTSD (Black \& White, 2005); breast cancer patients with strong Sense of Coherence perceived their days as less stressful, experienced a higher QoL, and had better health status; in addition, high Sense of Coherence also facilitated the selection of the most appropriate coping skills such as direct action, relaxation, distraction, or situation redefinition (Sarenmalm, Browall, Persson, Fall-Dickson \& Gaston-Johansson, 2011). The respective data represents the favourable 
results of high Sense of Coherence, which are, based on our own study, more effectively triggered by hypnosis intervention than music or special attention.

PICI has 16 scales that categorize the various components of psychological immunity. The question is how these components change in time during the chemotherapy and in the follow-up period. Comparing the results of PICI at the point of diagnosis (T1), after 12 weeks of treatment (T2), at the end of the chemotherapeutic treatment (T3), and at a one-year follow-up (T4), five components of the PICI scale demonstrated an increase in time: Positive Thinking, Sense of Control, Sense of Coherence, Emotional Control, and Impulse Control. The remaining scales were mainly stable in time or fluctuate around an average value during the examined period. There is no scale that demonstrated a monotonous decrease. The stability of PICI scales in time can be explained by the fact that psychological immunity has immune traits that enables individuals to handle stress individualspecific ways and grants a fast recovery (Oláh, 2005a). At the same time, increases on PICI scales in time can be interpreted in the framework of posttraumatic growth. According to Calhoun \&Tedeschi (2006), the first phase, after encountering the trauma, is characterized by automatic ruminations; later, when the trauma is integrated, more conscious coping strategies take its place. With conscious cognitive and emotional efforts, the phase of meaning-making may be reached. The increases in Positive Thinking, Sense of Control, Sense of Coherence, and control functions in time may be part of the phase of conscious processing that is triggered by psychological interventions.

It is worth to mention that there was a considerable Time $\times$ Group interaction in the case of Synchronicity. In the concept of Psychological Immune System, Synchronicity stands for the capacity to change, to act promptly according to environmental demands and ongoing events, to be flexible in solving actual problems and adapting to life situations at the appropriate time. Results indicated that in the case of the music group, the level of synchronicity constantly grew in the year following the diagnosis, while in the special attention group, the level of synchronicity varied around the same level. In the hypnosis group, synchronicity showed a greater increase during the periods of chemotherapy, i.e., during those situations that required flexible and quick adaptation. In contrast, Synchronicity fell back almost to the original level a year after the diagnosis when life returned to normal.

In summary, it seems that the psychological immune capacity of the breast cancer patients of our study reflects an increase over time as a result of successfully coping with the disease, independently from the intervention they received. At the same time, hypnosis seems to be able to further facilitate those coping skills in one's psychological immune competence 
that are already proven to be behind a better adaptation to cancer. Moreover, it may be assumed that hypnosis, directly giving suggestions, is more effective than non-directive music and special attention in developing adaptive coping strategies. As a further implication, hypnosis as a costeffective intervention - most probably due to the subjective feeling of increased coping capacity and psychological immunity - seems to reduce side-effects like nausea, vomiting, and the occurrence of anaphylaxis in this study (Kissné Jakubovits, 2014). These positive changes occur in spite of the negative physical and emotional side effects of chemotherapy, during a time that is usually described as stressful and straining. The conclusion may be drawn, then, that similar psychological interventions may contribute to the development and maintenance of adaptive coping potentials.

Several limitations should also be addressed. One of the limitations of the study is the relatively small sample size; at the same time, this small sample is characterized by homogeneity in both diagnosis and treatment. Therefore, the findings of the present study cannot be generalized across other cancer groups. Measuring psychological immunity was based exclusively on an 80-item self-reported questionnaire. Listening to a prerecorded series of positive suggestions through mp3 player is a costeffective way to reach large number of patients in the overwhelmed health systems; however, it lacks the personalized elements of a therapy that could also have an effect on the results. There are further important psychological factors that could affect coping capacity and psychological immunity, such as social support, personality traits, or perceived level of distress experienced during cancer treatment; these factors should be measured and controlled in future research studies. Nevertheless, the present study broadens the existing literature by providing a better understanding of breast cancer patients' characteristics of psychological immunity and its changes due to psychological interventions.

\section{References}

Bányai, É. (2013). „Psychological Resources and Healing” (The effect of adjuvant hypnotherapy on survival, immune functions and quality of life of intermediate and high risk breast cancer patients). Hungarian Scientific Research Fund - OTKA K109187 grant. Budapest.

Bányai, É., \& Vargay, A. (2013). Zenehallgatás, mint a hipnózis kontrollja: elméleti és módszertani megfontolások. XXIV. Magyar Hipnózis Találkozó: Egymás hullámhosszán - Zene, ritmus és hipnózis, Budapest. 2013. május 24-26.

Bányai, É.I., Józsa, E., Jakubovits, E., Vargay, A., Zsigmond, O., \& Horváth, Zs. (2017). Evidence based research on the role of hypnosis as a psychological intervention in the care of breast cancer patients: a randomised prospective controlled study. PsychoOncology, 26, 61 . 
Bargard, I., Etienne, A.M., Faymonville, M.E., Coucke, P., Lifrange, E., Schroeder, H., et al. (2017). A nonrandomized comparison study of self-hypnosis, yoga and cognitivebehavioural therapy to reduce emotional distress in breast cancer. International Journal of Clinical and Experimental Hypnosis, 65(2), 189-209.

Barling, N.R., \& Raine, S.J. (2005). Some effects of hypnosis on negative affect and immune system response. International Journal of Clinical and Experimental Hypnosis, 33(2), 160-177.

Black, E.K., \& White, C.A. (2005). Fear of recurrence, sense of coherence and posttraumatic stress disorder in haematological cancer survivors. Psycho-Oncology, 14, 510-515.

Calhoun, L.G., \& Tedeschi, R.G. (2006). The foundations of posttraumatic growths: An expanded framework. In L.G. Calhoun, \& R.G. Tedeschi (Eds.), Handbook of posttraumatic growth - Research practice (3-23). London: Lawrence Erlbaum Associates.

Cardena, E., Svensson, C., \& Hejdstrom, F. (2013). Hypnotic tape intervention ameliorates stress: a randomized, control study. International Journal of Clinical and Experimental Hypnosis, 61(2), 125-145.

Carvalho, J.P., \& Hopko, D.R. (2009). Treatment of a depressed breast cancer patient with problem-solving therapy. Clinical Case Studies, 8(4), 263-276.

Cegala, D.J. (2003). Patient communication skills training: a review with implications for cancer patients. Patient Education and Counselling, 50(1), 91-94.

Chen, P.Y., Liu, Y.M., \& Chen, M.L. (2017). The Effect of Hypnosis on Anxiety in Patients with Cancer: A Meta-Analysis. Worldviews on Evidence-Based Practic,14(3), 223-236.

Conley, C.C., Bishop, B.T., \& Andersen, B.L. (2016). Emotions and Emotion Regulation in Breast Cancer Survivorship. Healthcare, 4(3), 56.

D’Agostino, T.A., Atkinson, T.M., Latella, L.E., Rogers, M., Morissey, D., DeRosa, A.P., et al. (2017). Promoting patient participation in healthcare interactions through communication skills training: A systematic review. Patient Education and Counseling, 100(7), 1247-1257.

Elkins, G., Barabasz, A., Council, J. \& Spiegel, D. (2015). Advancing Research and Practice: The Revised APA division 30 Definition of Hypnosis. International Journal of Clinical and Experimental Hypnosis, 63(1), 1-9.

Geyer, S., Koch-Giesselmann, H., \& Noeres, D. (2015). Coping with breast cancer and relapse: Stability of coping and long-term outcomes in an observational study over 10 years. Social Science \& Medicine, 135, 92-98.

Goldhirsch, A., Wood, W.C., Coates, A.S., Gelber, R.D., Thurlimann, B., \& Senn, H.J. (2011). Strategies for subtypes - dealing with the diversity of breast cancer: highlights of the St. Gallen International Expert Consensus on the Primary Therapy of Early Breast Cancer. Annals of Oncology, 22(8), 1736-1747.

Groarke, A., Curtis, R. \& Kerin, M. (2013). Cognitive-behavioral stress management enhances adjustment in woman with breast cancer. British Journal of Health Psychology, 18(3), 623-641.

Gudenkauf. L.M., Antoni, M.H., Stagl, J.M., Lechner, S.C., Jutagir, D.R., Bouchard, L.C., et al. (2015). Brief cognitive-behavioral and relaxation training interventions for breast cancer: A randomized controlled trial. Journal of Consulting and Clinical Psychology, 83(4), 677-688.

Gupta, R., \& Pandey, R. (2014). Sense of Coherence and Self-Compassion as Potential Psychological Adaptogens for Suicide: An Overview. American Journal of Life Science Researches, 11, 75-88.

Henselmans, I., Fleer, J., de Vries, J., Baas, C.P., Sanderman, R., \& Ranchor, A.V. (2010). The adaptive effect of personal control when facing breast cancer: Cognitive and behavioural mediators. Psychology \& Health, 25(9), 1023-1040. 
Hervatin, R., Sperlich, S., Koch-Giesselman, H., \& Geyer, S. (2012). Variability and stability of coping in women with breast cancer. Supportive Care in Cancer, 20(10), 2277-2285.

Hopko, D.R., Armento, M.EA., Robertson, S., Ryba, M.M., Carvalho, J.P., Colman, L.K.., et al. (2011). Brief behavioural activation and problem-solving therapy for depressed breast cancer patients: randomized trial. Journal of Consulting and Clinical Psychology, 79(6), 834.

Kim, J., Han, J.Y., Shaw, B., McTavish, F., \& Gustafson, D. (2010). The roles of social support and coping strategies in predicting breast cancer patients' emotional well-being. Testing mediation and moderation models. Journal of Health Psychology, 15(4), 543-552.

Kissné Jakubovits, E. (2014). The effects of suggestive communication on the physical state of the patient in critical medical situations - Decreasing the side-effects encountered by breast cancer patients during chemotherapy with adjuvant hypnotherapy (Unpuplished doctoral dissertation). Eötvös Loránd University, Faculty of Education and Psychology, Budapest.

Kvillemo, P., \& Bränström, R. (2014). Coping with breast cancer: a meta-analysis. PloS one, 9(11): e112733. Doi: 10.1371/journal.pone.0112733

Lazarus, R.S., \& Folkman, S. (1984). Stress, appraisal and coping. New York: Springer

Magyaródi T., Nagy H., Soltész P., Mózes T., \& Oláh A. (2014). The electrophysiological correlates of personality and the psychological immune system under different conditions. In A. Oláh, \& H. Nagy (Eds.), Flow, Emotional Intelligence and Psychological Immunity: Empirical Studies in Positive Psychological Perspective (157-168). Budapest: ELTE Eötvös Kiadó

Mirnics, Z., Heincz, O., Bagdy, G., Surányi, Z., Gonda, X., Benkő, A., et al. (2013). The relationship between the big five personality dimensions and acute psychopathology: mediating and moderating effects of coping strategies. Psychiatria Danubina, 25(4), 379388.

Nagy H., \& Oláh A. (2014) The components of emotional intelligence and psychological immunity. In A. Oláh, \& H., Nagy (Eds.), Flow, Emotional Intelligence and Psychological Immunity: Empirical Studies in Positive Psychological Perspective (137-140). Budapest: ELTE Eötvös Kiadó

Nezu, A.M., Nezu, C.M., Felgoise, S.H., McClure, K.S., \& Houts, P.S. (2003). Project Genesis: assessing the efficacy of problem-solving therapy for distressed adult cancer patients. Journal of Consulting and Clinical Psychology, 71(6), 1036-1048.

Oláh, A. (2005a). Anxiety, coping, and flow. Empirical studies in interactional perspective. Budapest: Trefort Press

Oláh, A. (2005b). Érzelmek, megküzdés és optimális élmény. Budapest: Trefort Kiadó

Oláh, A. (2009). Psychological immunity: A new concept of coping and resilience. Coping \& Resilience International Conference, Dubrovnik - Cavtat, Croatia, 2009. October 3-6.

Oláh, A., Nagy, H., \& Tóth, G.K. (2010): Life Expectancy and Psychological Immune Competence in Different Cultures. Empirical Text and Culture Research, 4(2010), 102-108.

Regier, N.G., \& Parmelee, P.A., (2015). The stability of coping strategies in older adults with osteoarthritis and the ability of these strategies to predict changes in depression, disability, and pain. Aging \& Mentel Health, 19(12), 1-10.

Reyna, V.F., Nelson, W.L., Han, P.K., \& Pignone, M.P. (2015). Decision making and cancer. American Psychologist, 70(2), 105-118.

Roussi, P., Krikeli, V., Hatzidimitriou, C., \& Koutri, I. (2007). Patterns of coping, flexibility in coping and psychological distress in women diagnosed with breast cancer. Cognitive Therapy and Research, 31, 97-109.

Sarenmalm, K.E., Browall, M., Persson, LO., Fall-Dickson, J., \& Gaston-Johansson, F. (2011). Relationship of sense of coherence to stressful events, coping strategies, health status, and quality of life in women with breast cancer. Psycho-Oncology, 22(1), 20-27. 
Scheenen, M.E., van der Horn, H.J., de Koning, M.E., van der Naalt, J., \& Spikman, J.M. (2017). Stability of coping and the role of self-efficacy in the first year following mild traumatic brain injury. Social Science and Medicine, 181, 184-190.

Schoen, M., \& Nowack, K. (2013). Reconditioning the stress response with hypnosis CD reduces the inflammatory cytokine IL-6 and influences resilience: A pilot study. Complementary Therapies in Clinical Practice, 19, 83-88.

Schroevers, M.J., Helgeson, V.S., Sanderman, R., \& Ranchor, A.V. (2009). Type of social support matters for prediction of posttraumatic growth among cancer survivors. PsychoOncology, 19(1), 46-53.

Shapiro, J.P, McCue, K., Heyman, E.N, Dey, T., \& Haller, H.S. (2010). Coping-related variables associated with individual differences in adjustment to cancer. Journal of Psychosocial Oncology, 28, 1-22.

Shor, R.E. (1962). Three dimensions of hypnotic depth. International Journal of Clinical and Experimental Hypnosis, 10(1), 23-38.

Stagl, J.M., Bouchard, L.C., Lechner, S.C., Blomberg, B.B., Gudenkauf, L.M., Jutagir, D.R., et al. (2015). Long-term psychological benefits of cognitive-behavioral stress management for woman with breast cancer: 11-year follow-up of a randomized control trial. Cancer, 121(4), 1873-1881.

Stanton, A.L., Danoff-Burg, S., \& Cameron, C.L. (2000). Emotionally expressive coping predicts psychological and physical adjustment to breast cancer. Journal of Consulting and Clinical Psychology, 68(5), 875-882.

Stanton, H.E. (1989). Hypnosis and rational-emotive therapy - a de-stressing combination: a brief communication. International Journal of Clinical and Experimental Hypnosis, 37(2), 95-99.

Szicsek, M. (2004). A kiégés és a pszichológiai immunkompetencia összefüggései az ápolói munkában. KHARÓN Thanatológiai Szemle, 8(1-2), 88-131.

Usta, Y.Y. (2012). Importance of social support in cancer patients. Asian Pacific Journal of Cancer Prevention, 13(8), 3569-3572.

Voitkane, S. (2004). Goal directedness in relation to life satisfaction, psychological immune system and depression in first-semester university students in Latvia. Baltic Journal of Psychology, 5(2), 19-31.

Wang, A.W.T., Bouchard, L.C., Gudenkauf, L.M., Jutagir, D.R., Fisher, H.M., Jacobs, J.M., et al. (2018). Differential psychological effects of cognitive-behavioral stress management among breast cancer patients with high and low initial cancer-specific distress. Journal of Psychosomatic Research, 113, 52-57.

\section{Acknowledgement}

The authors wish to thank the Hungarian Scientific Research Fund (OTKA/NKFI, project number: K109187) for sponsoring our research study; "PSYHOLOGICAL RESOURCES AND HEALING".

\section{Authors' contribution}

$\mathrm{AV}, \mathrm{AP}$ and ÉB summarised the scientific background of the paper. AV, EJ, and ÉB collected the data. AV carried out the statistical analysis. AV, AP, EJ, and ÉB finalised the text. ÉB is the principal investigator. 


\title{
Conflicts of interest
}

The authors declare that there are no conflicts of interest that would affect the study result and their interpretation.

\section{A pszichológiai immunkompetencia jellemzói és változásai hipnózisban, zenében vagy kiemelt figyelemben részesülő emlődaganatos betegek esetében}

\author{
VARGAY ADRIENN - JÓZSA EMESE - PÁJER ALEXANDRA - \\ BÁNYAI ÉVA
}

Elméleti háttér: A megküzdési mechanizmusoknak és adaptációs készségeknek fontos szerepe van az emlődaganatos betegségekhez való alkalmazkodásban. A pszichológiai immunrendszer olyan személyiségforrásokat integrál, melyek a sikeres megküzdést biztosítják. A hipnózis, mint pszichológiai intervenció bizonyítottan képes a megküzdési kapacitás növelésére, azonban a pszichológiai immunrendszerre gyakorolt hatását eddig keveset vizsgálták. Célkitüzés: Célunk emlődaganatos betegek pszichológiai immunkompetenciájának vizsgálata, és különböző pszichológiai intervenciók pszichológiai immunrendszerre gyakorolt hatásának összehasonlítása. Módszer: Emlődaganatos betegek standard kemoterápiáját kiegészítő adjuváns hipnózis, zene, illetve kiemelt figyelem hatását vizsgáltuk. A pszichológiai immunrendszer jellemzőit a Pszichológiai Immunkompetencia Kérdőív (PIK) segítségével négy alkalommal mértük. Eredmények: A különböző intervenciók hatására a PIK több skáláján is szignifikáns különbség volt kimutatható az egyes csoportok között Társas monitorizálás/empátia $\left(F(2,58)=5,973 ; p=0,006 ; \omega^{2}=\right.$ $0,12)$; Leleményesség $\left(F(2,58)=4,208 ; p=0,023 ; \omega^{2}=0,10\right)$; Impulzus kontroll $(F(2,58)=$ 6,$\left.051 ; p=0,005 ; \omega^{2}=0,11\right)$; Érzelmi kontroll $\left(F(2,58)=3,612 ; p=0,037 ; \omega^{2}=0,07\right)$ skálákban a kemoterápiás kezelés alatt és Kontroll érzés $\left(F(2,58)=6,548 ; p=0,004 ; \omega^{2}=0,11\right.$ ); Koherencia érzés $\left(F(2,58)=4,898 ; p=0,013 ; \omega^{2}=0,10\right)$; Leleményesség $(F(2,58)=3,949 ; p=$ 0,$\left.028 ; \omega^{2}=0,08\right)$ skálákban a kezelés után. Összességében a Hipnózis csoport betegei magasabb pszichológiai immunkompetenciával jellemezhetók a többi csoporthoz képest. A PIK időbeni változását vizsgálva mindhárom csoportban az immunkompetencia növekedése volt megfigyelhető mind a PIK összpontszámban $(F(3,174)=6,403 ; p<0,001$; $\left.\eta^{2} p=0,10\right)$, mind a PIK egyes skáláin. Interakciós hatás csak a Szinkronicitás skála esetében jelentkezett $\left(F(2,58)=2,508 ; p=0,024 ; \eta^{2} p=0,08\right)$. Konklúzió: A pszichológiai immunkompetencia a pszichológiai intervenciók során növekedést mutatott a kemoterápiás kezelés és az utánkövetés alatt is, függetlenül az intervenció fajtájától. Emellett a pszichológiai immunitás megtartásában és növelésében a hipnózis facilitáló szerepe is megjelenik a daganatos betegség kezelése során.

Kulcsszavak: emlődaganat, pszichológiai intervenció, hipnózis, megküzdés, pszichológiai immunkompetencia

This is an open-access article distributed under the terms of the Creative Commons Attribution 4.0 International License (https://creativecommons.org/licenses/by/4.0/), which permits unrestricted use, distribution, and reproduction in any medium, provided the original author and source are credited, a link to the CC License is provided, and changes - if any - are indicated. (SID_1) 